\title{
Comparative study of some analytical methods to quantify lignin concentration in tropical grasses
}

\author{
Alejandro V. Velásquez ${ }^{1, *}$, Cristian M. M. R. Martins ${ }^{1}$, Pedro Pacheco ${ }^{1}$, and Romualdo S. Fukushima ${ }^{1}$
}

* Corresponding Author: Alejandro V. Velásquez Tel: +55-34-99920-0381,

E-mail: alejandrovavel@usp.br

'Departamento de Nutrição e Produção Animal, Faculdade de Medicina Veterinária e Zootecnia, University of São Paulo, Av. Duque de Caxias, 225 Pirassununga, SP 13630-900, Brazil

ORCID

Alejandro V. Velásquez

https://orcid.org/0000-0002-6435-8963

Cristian M. M. R. Martins

https://orcid.org/0000-0002-3476-3458

Pedro Pacheco

https://orcid.org/0000-0002-3388-6114

Romualdo S. Fukushima

https://orcid.org/0000-0002-7781-8367

Submitted Jun 13, 2017; Revised Jul 13, 2017; Accepted Feb 5, 2018
Objective: Lignin plays a relevant role in the inhibition of cell wall (CW) structural carbohydrate degradation. Thus, obtaining accurate estimates of the lignin content in tropical plants is important in order to properly characterize the mechanism of lignin action on CW degradation. Comparing conflicting results between the different methods available for commercial use will bring insight on the subject. This way, providing data to better understand the relationship between lignin concentration and implications with tropical forage degradation.

Methods: Five grass species, Brachiaria brizantha cv Marandú, Brachiaria brizantha cv Xaraés (MG-5), Panicum maximum cv Mombaça, Pennisetum purpureum cv Cameroon, and Pennisetum purpureum cv Napier, were harvested at five maturity stages. Acid detergent lignin (ADL), Klason lignin (KL), acetyl bromide lignin (ABL), and permanganate lignin (PerL) were measured on all species. Lignin concentration was correlated with in vitro degradability.

Results: Highly significant effects for maturity, lignin method and their interaction on lignin content were observed. The ADL, KL and ABL methods had similar negative correlations with degradability. The PerL method failed to reliably estimate the degradability of tropical grasses, possibly due to interference of other substances potentially soluble in the $\mathrm{KMnO}_{4}$ solution.

Conclusion: $\mathrm{ADL}$ and $\mathrm{KL}$ methods use strong acid $\left(\mathrm{H}_{2} \mathrm{SO}_{4}\right)$ and require determination of ash and $\mathrm{N}$ content in the lignin residues, therefore, increasing time and cost of analysis. The ABL method has no need for such corrections and is a fast and a convenient method for determination of total lignin content in plants, thus, it may be a good option for routine laboratory analysis.

Keywords: Lignin; Acetyl Bromide; Degradability; Acid Detergent

\section{INTRODUCTION}

Ruminants are highly dependent on forages as a source of energy and a large portion of this energy comes from the plant cell wall (CW) [1]. However, utilization of this energy source may be limited if a substantial portion of what is ingested is not digested, ultimately being excreted in the feces. Lignin has been considered one of the most limiting factors of CW degradation [2], thus, the determination of lignin quantity is essential, to better asses the mechanisms by which lignin inhibits CW degradation.

The more commonly used methods can be classified into two categories: i) those that remove the CW constituents except lignin, and ii) those that breakdown the lignin polymer separating it from the CW structure. In the first category, two procedures that use concentrate (72\%) sulfuric acid result in an insoluble acid residue, after hydrolysis of CW polysaccharides. Such is the case of acid detergent lignin (ADL) and Klason lignin (KL) [3]. However, ADL may underestimate lignin due to its partial solubilization in the acid detergent solution (ADS) [4-7] or in the $72 \%$ sulfuric acid solution [8]. Also, lignin from the KL method can be con- 
taminated with $\mathrm{N}$ residues [8].

In the second category, lignin can be determined by the difference in weight after lignin degradation with oxidizing reagents, such as potassium permanganate. However, this procedure can also oxidize other substances (e.g. pectin, flavonoids, tannins, etc.) that are not completely removed during the fibrous fraction preparation, and are measured as being lignin [9].

An alternative method for lignin quantification that does not fit in neither of the previous categories is the acetyl bromide lignin (ABL) method. In this procedure, solubilized lignin in $25 \%$ acetyl bromide solution is read on a spectrophotometer at UV wavelength region of $280 \mathrm{~nm}$ [10].

In spite of the various available methods, none of them can be considered as a standard for all types of materials. Knowledge of lignin concentrations help to better understand the degradability of forages, cellulose pulp production and second generation ethanol production. Then, the question of which is the best method for measuring lignin arises. This determination has to be made on the basis of method accuracy and precision, its simplicity, time for analysis and cost per sample, among other factors. The objective of this study was to evaluate $\mathrm{ADL}$, potassium permanganate lignin (PerL), and KL methods for determining lignin in forages and to compare their results to those obtained by the $\mathrm{ABL}$ procedure. Also, to correlate results of lignin concentration with in vitro degradability.

\section{MATERIALS AND METHODS}

\section{Samples}

Five grass species, Brachiaria brizantha cv Marandú, Brachiaria brizantha cv Xaraés (MG-5), Panicum maximum cv Mombaça, Pennisetum purpureum cv Cameroon and Pennisetum purpureum cv Napier, were harvested at five maturity stages with 15 day intervals between each cut, after an initial uniformization cut. The maturity stages were pre-flower head emergence 1 (35 days), pre-flower head emergence 2 (50 days), initial flowering ( 65 days), total flowering (80 days), and post-flowering (95 days).

\section{Chemical analyses}

Fresh samples were weighed and dried in a forced ventilation oven at $60^{\circ} \mathrm{C}$, for 72 hours. Dried samples were ground using a Wiley type laboratory knife mill with a $0.5 \mathrm{~mm}$ screen. After processing, samples were stored in closed glass containers.

Neutral detergent fiber (NDF) and acid detergent fiber (ADF) (sequentially after NDF) were determined as described by Van Soest et al [11]. To obtain fiber preparations, non-woven textile (NWT; $100 \mathrm{~g} / \mathrm{m}^{2}$ ) bags were used. Heat-stable bacterial alpha amylase (Termamyl $2 x$, activity $=17,400$ Liquefon Units/mL, TECNOGLOBO, Curitiba, PR, Brazil) was used to prepare NDF but no sodium sulfite was added. The ADL was determined as described by Van Soest and Robertson [12].

The CW which is used as a fibrous substrate for the ABL procedure was prepared according to the protocol proposed by Fukushima et al [7]. The NDF fraction was corrected for residual ash [13], as well as CW, and crude protein was determined by using the Kjeldahl procedure. Equivalent protein was determined by using the 6.25 factor to convert $\mathrm{N}$ content into crude protein.

ADF was used as a fibrous substrate for ADL and PerL analyses. Approximately $500 \mathrm{mg}$ of ADF dry matter (DM) sample was weighed in NWT bags. After ADF extraction, the bags were placed in a beaker and covered with $72 \%$ sulfuric acid solution (approximately $30 \mathrm{~mL}$ of acid per bag). An Erlenmeyer containing $150 \mathrm{~mL}$ of water was placed inside the beaker in order to maintain the bags submerged in the acid solution. The procedure lasted three hours and the acid solution was changed once. Following the acid treatment, bags were carefully rinsed off with distilled water, transferred to another glass beaker containing hot distilled water and left to soak for approximately 12 hours. During this period, water was replenished in order to keep it hot and $\mathrm{pH}$ was measured using $\mathrm{pH}$ strips to monitor the presence of any acid residue in the bags. Finally, the bags were placed to dry in a forced ventilation oven at $105^{\circ} \mathrm{C}$, overnight. After being weighed, bags were incinerated in a muffle furnace in order to correct ADL values for ash presence.

KL was performed as proposed by Hatfield et al [8]. This method is also based on $72 \%$ sulfuric acid hydrolysis of CW components, except lignin. Differently from the ADL method, $\mathrm{KL}$ uses dietary fiber (DF) as a substrate, instead of ADF. Briefly, approximately $250 \mathrm{mg}$ of DF samples were placed inside 120 $\mathrm{mL}$ screw capped bottles. Three milliliters of $12 \mathrm{M}$ sulfuric acid solution were added to each bottle and the contents stirred with a glass rod. The bottles were kept in a $30^{\circ} \mathrm{C}$ water bath for 60 minutes, after which $80 \mathrm{~mL}$ of distilled water was added to each one. Subsequently, the bottles were autoclaved at $105^{\circ} \mathrm{C}$ for 1 hour. Once autoclaved, the insoluble material was vacuum-filtered in glass crucibles, washed with hot distilled water and dried overnight at $105^{\circ} \mathrm{C}$. Finally, ash content was determined.

PerL analysis was performed as described by Van Soest and Wine [9]. Approximately $500 \mathrm{mg}$ of ADF preparation was placed inside glass-crucibles. Each crucible was filled with saturated $\mathrm{KMnO}_{4}$ solution (approximately $30 \mathrm{~mL} /$ crucible). The content inside the crucible was stirred occasionally using individual glass rods. After filtering under vacuum, this step was repeated once more. The crucibles were filtered and 30 $\mathrm{mL}$ of demineralizing solution was added. After 20 minutes, the demineralizing solution was replenished and the crucibles were left to sit for 20 more minutes. Then, the residue was vacuum-filtered and washed three times with approximately $20 \mathrm{~mL}$ (each time) of ethanol solution $(800 \mathrm{~mL} / \mathrm{L})$ and acetone. 
The ABL procedure uses CW as a substrate [7]. Approximately $100 \mathrm{mg}$ CW sample were weighed in glass centrifuge tubes fitted with teflon lined caps. A blank control tube was also conducted. Ten $\mathrm{mL}$ of a solution of acetyl bromide in acetic acid $(250 \mathrm{~mL} / \mathrm{L})$ were added. The tubes were then kept in a $50^{\circ} \mathrm{C}$ water bath for 2 hours, having their contents gently stirred every 30 minutes. After cooling down, the tubes were centrifuged at $2,000 \times \mathrm{g}$ for 15 minutes. Aliquots $(0.5 \mathrm{~mL})$ of the solution were pipetted into test-tubes that contained $6.5 \mathrm{~mL}$ of glacial acetic acid and $2 \mathrm{~mL}$ of a $0.3 \mathrm{M} \mathrm{NaOH}$ solution. After stirring, one milliliter of $0.5 \mathrm{M}$ hydroxylamine hydrochloride solution was added and the contents again stirred.

The absorbance of the solution was determined on a Libra S80 spectrophotometer (BIOCHROM, Cambridge, UK) at a wavelength of $280 \mathrm{~nm}$ and inserted in the equation proposed by Fukushima and Kerley [14]:

$$
L=\frac{A-0.0009}{23.077}
$$

Where $L$ is the lignin concentration $(\mathrm{mg} / \mathrm{mL}), A$ is the absorbance (optical density reading) of the unknown sample, 0.0009 is the mean intercept value and 23.077 is the mean extinction coefficient. The resulting $L$ value is then multiplied by the CW content of the plant (on a DM basis) and divided by the actual amount of CW utilized after all dilutions (mg of CW weighed divided by 200). This gives the lignin concentration in the plant $(\mathrm{g} / \mathrm{kg} \mathrm{DM})$.

In the $\mathrm{ABL}$ procedure it is recommended that all analysis steps be made in a ventilated hood because the acetyl bromide fumes are irritating for the respiratory tract and vision mucosa. When dosing acetyl bromide solution, it is also recommended to use syringe-type pipettes with positive air displacement, so that the fumes will not damage the pipette. In spite of this, the acetyl bromide reagent is far less corrosive than the $72 \% \mathrm{H}_{2} \mathrm{SO}_{4}$ solution used in the other procedures.

\section{In vitro degradation trials}

For the degradability trials an adapted Tilley and Terry [15] method was used. Briefly, approximately $500 \mathrm{mg}$ of sample were placed in F-57 bags, $25 \mu \mathrm{m}$ pore size (ANKOM Technology Corp, Macedon, NY, USA) and incubated in McDougall's buffer solution and ruminal fluid, at a 4:1 ratio, for 48 hours. After this, a pepsin and hydrochloric acid solution were added and the samples incubated for another 48 hours. The anaerobic environment in the McDougall solution was attained faster by using the technique proposed by Fukushima et al [16].

\section{Experimental design}

A completely randomized experimental design with duplicate analysis for the lignin assays was used. The lignin contents obtained by the different methods were compared between species and maturity stages according to the model:

$$
Y_{i j k}=\mu+A_{i}+S j+M_{k}+A M_{i k}+\varepsilon_{i j k}
$$

Where $Y_{i j k}$ is the dependant variable; $\mu$ is the general constant; $A_{i}$ is the effect of the analytical method $i$ (random effect); $S_{j}$ is the effect of the species $j$ (fixed effect); $M_{k}$ is the effect of maturity level $k$ (fixed effect); $A M_{i k}$ is the interaction effect of the analytical method $i$ and the maturity level $k ; \varepsilon_{i j k}$ is the random error.

A randomized block design was used for the in vitro experiment, with rumen fluid blocked by week. Individual treatment means were compared by Tukey's test $(\mathrm{p}<0.05)$. Correlation coefficients between lignin methods and in vitro degradability values were obtained using PROC CORR from SAS 9.1 [17].

The relationship between the lignin concentrations obtained by four different methods and the characteristics of in vitro degradability (DM and NDF) were evaluated by linear regression according to the basic model:

$$
Y_{i j}=\beta_{0}+\beta_{1} \times S+\beta_{2} \times L_{i j}+\beta_{3} \times\left(S \times L_{i j}\right)+\varepsilon_{i j}
$$

Where $Y_{i j}$ is the dependent variable observed in maturity level $j$ of analytical method $i ; \beta_{0}$ is the intercept; $\beta_{1,2,3}$ are coefficients for species, lignin and their interaction, respectively; $L_{i j}$ is the lignin content $(\mathrm{g} / \mathrm{kg} \mathrm{DM}) ; S$ is the variable corresponding to the specie; and $\varepsilon_{i j}$ is the random error.

All statistical procedures were performed using PROC MIXED of SAS 9.1 [17] $(\alpha=0.05)$.

\section{RESULTS}

\section{Chemical composition}

Chemical composition of the five grass species is depicted in Table 1. The CW, NDF, and ADF increased as the plants matured $(\mathrm{p}<0.0001)$. For all species at any given maturity, CW values were numerically higher (no statistics run) than the corresponding NDF values. What differentiates CW from $\mathrm{NDF}$ is that the latter has the neutral detergent soluble carbohydrates (pectin, $\beta$-glucans, galactans, gums, etc.) removed. Then, an estimate of the soluble fiber (SF) fraction is practical $(\mathrm{SF}=\mathrm{CW}-\mathrm{NDF})$ and aids to better characterize the animal feeds [18]. Estimates of SF concentrations were similar among grass species except for Marandú, which SF concentration was higher $(\mathrm{p}<0.0001)$ with mean value of $99.8 \mathrm{~g} / \mathrm{kg} \mathrm{DM}$.

\section{Lignin concentrations}

The effect for method of lignin quantification was highly significant $(\mathrm{p}<0.0001)$ for all plant species as they matured. The interaction between the two variables was significant for Marandú, Xaraés, Cameroon $(\mathrm{p}<0.0001)$ and for Napier $(\mathrm{p}=0.0003)$. The interaction was not significant for Mombaça 
Table 1. Mean chemical composition ( $\mathrm{g} / \mathrm{kg}$ DM) of five grass species at different maturity levels

\begin{tabular}{|c|c|c|c|c|c|}
\hline Maturity & $\mathrm{CW}^{1)}$ & NDF $^{1)}$ & $\mathrm{SF}^{2)}$ & IVDMd & IVNDFd \\
\hline & \multicolumn{5}{|c|}{ Brachiaria brizantha cv Marandú } \\
\hline 1 & 586.7 & 481.3 & 107.6 & 652.2 & 487.9 \\
\hline 2 & 645.2 & 543.9 & 101.3 & 612.2 & 454.0 \\
\hline 3 & 666.6 & 565.4 & 101.2 & 556.8 & 337.1 \\
\hline 4 & 692.7 & 595.8 & 96.9 & 439.1 & 220.0 \\
\hline 5 & 720.2 & 621.9 & 98.3 & 478.3 & 275.0 \\
\hline Mean & 662.3 & 561.7 & 101.1 & 547.7 & 354.8 \\
\hline \multirow[t]{2}{*}{ SE } & 13.9 & 14.7 & 1.6 & 19.6 & 24.5 \\
\hline & \multicolumn{5}{|c|}{ Brachiaria brizantha cv Xaraés } \\
\hline 1 & 695.2 & 636.3 & 58.9 & 616.6 & 543.7 \\
\hline 2 & 722.5 & 688.8 & 33.9 & 571.8 & 480.2 \\
\hline 3 & 747.1 & 718.9 & 28.2 & 509.0 & 431.5 \\
\hline 4 & 782.2 & 753.9 & 28.4 & 448.1 & 360.0 \\
\hline 5 & 795.1 & 769.2 & 25.9 & 402.5 & 303.8 \\
\hline Mean & 748.4 & 713.4 & 35.1 & 509.6 & 423.8 \\
\hline \multirow[t]{2}{*}{ SE } & 13.9 & 16.9 & 3.5 & 22.2 & 23.7 \\
\hline & \multicolumn{5}{|c|}{ Panicum maximum cv Mombaça } \\
\hline 1 & 642.8 & 607.0 & 35.9 & 656.8 & 580.4 \\
\hline 2 & 692.0 & 656.5 & 35.5 & 604.9 & 516.0 \\
\hline 3 & 722.7 & 689.1 & 33.5 & 595.4 & 509.0 \\
\hline 4 & 745.7 & 713.1 & 32.0 & 493.9 & 372.2 \\
\hline 5 & 749.4 & 717.2 & 32.3 & 439.7 & 307.4 \\
\hline Mean & 710.5 & 676.6 & 33.8 & 558.1 & 457.0 \\
\hline \multirow[t]{2}{*}{ SE } & 13.9 & 15.0 & 1.9 & 26.5 & 30.6 \\
\hline & \multicolumn{5}{|c|}{ Pennisetum purpureum cv Cameroon } \\
\hline 1 & 596.5 & 539.9 & 56.6 & 697.0 & 584.0 \\
\hline 2 & 647.3 & 617.5 & 29.6 & 627.7 & 511.1 \\
\hline 3 & 666.5 & 644.5 & 22.0 & 560.8 & 436.9 \\
\hline 4 & 670.3 & 653.0 & 17.4 & 499.2 & 384.1 \\
\hline 5 & 703.0 & 685.0 & 17.2 & 475.8 & 349.1 \\
\hline Mean & 656.7 & 628.0 & 28.6 & 572.1 & 453.0 \\
\hline \multirow[t]{2}{*}{ SE } & 12.3 & 15.4 & 4.2 & 22.2 & 23.1 \\
\hline & \multicolumn{5}{|c|}{ Pennisetum purpureum cv Napier } \\
\hline 1 & 671.0 & 613.7 & 57.4 & 662.0 & 616.0 \\
\hline 2 & 688.5 & 642.0 & 46.5 & 577.6 & 519.3 \\
\hline 3 & 704.1 & 667.8 & 36.2 & 535.4 & 455.5 \\
\hline 4 & 726.5 & 693.8 & 32.7 & 476.8 & 371.6 \\
\hline 5 & 740.4 & 716.8 & 24.6 & 445.2 & 340.1 \\
\hline Mean & 706.1 & 666.8 & 39.5 & 539.4 & 460.5 \\
\hline SE & 10.5 & 13.9 & 4.0 & 22.8 & 28.8 \\
\hline
\end{tabular}

DM, dry matter; CW, cell wall; NDF, neutral detergent fiber; SF, soluble fiber; IVDMd, in vitro dry matter degradability; IVNDFd, in vitro neutral detergent fiber degradability; SE, standard error of the mean.

1) Corrected for ash and protein.

2) $\mathrm{SF}=\mathrm{CW}-\mathrm{NDF}$.

$(\mathrm{p}=0.08)$.

Mean lignin concentrations varied widely among analytical methods. The ADL method yielded the lowest lignin concentrations $(p<0.0001)$ of the four methods. This result was consistently observed in all species at the five maturity stages. Values ranged from $28.1 \mathrm{~g} / \mathrm{kg}$ DM for Panicum maximum cv Mombaça, to $103.1 \mathrm{~g} / \mathrm{kg}$ DM for Brachiaria brizantha cv Xaraés
Table 2. Lignin concentrations ( $/ \mathrm{kg} \mathrm{DM}$ ) and mean SE obtained through four analytical procedures

\begin{tabular}{|c|c|c|c|c|}
\hline Maturity & ADL & $\mathrm{KL}$ & PerL & $A B L$ \\
\hline & \multicolumn{4}{|c|}{ Brachiaria brizantha cv Marandú } \\
\hline 1 & $39.0^{c c}$ & $71.5^{\mathrm{Db}}$ & $65.5^{\mathrm{Ec}}$ & $110.0^{\mathrm{ca}}$ \\
\hline 2 & $43.5^{B C d}$ & $83.4^{\mathrm{cc}}$ & $98.3^{\mathrm{CDb}}$ & $117.8^{\mathrm{ca}}$ \\
\hline 3 & $50.6^{B C}$ & $89.0^{\mathrm{cb}}$ & $110.8^{\mathrm{Ba}}$ & $118.1^{\mathrm{Ca}}$ \\
\hline 4 & $61.9^{A c}$ & $101.0^{B b}$ & $141.1^{\mathrm{Aa}}$ & $136.2^{\mathrm{Ba}}$ \\
\hline 5 & $71.3^{\mathrm{Ad}}$ & $116.2^{\mathrm{Ab}}$ & $94.4^{D c}$ & $151.4^{\mathrm{Aa}}$ \\
\hline Mean & 53.3 & 92.2 & 102.0 & 126.7 \\
\hline \multirow[t]{2}{*}{ SE } & 0.4 & 1.0 & 5.1 & 0.9 \\
\hline & \multicolumn{4}{|c|}{ Brachiaria brizantha cv Xaraés } \\
\hline 1 & $31.3^{D C}$ & $61.4^{\mathrm{Db}}$ & $94.9^{\mathrm{Ba}}$ & $97.4^{\mathrm{Da}}$ \\
\hline 2 & $47.4^{\mathrm{Cc}}$ & $82.6^{\mathrm{cb}}$ & $92.3^{\mathrm{Bb}}$ & $127.0^{\mathrm{Ca}}$ \\
\hline 3 & $50.2^{\mathrm{Cd}}$ & $96.3 \mathrm{BC}$ & $118.8^{\mathrm{cb}}$ & $131.8^{\mathrm{Ca}}$ \\
\hline 4 & $72.7^{\mathrm{Bd}}$ & $114.4^{\mathrm{AC}}$ & $99.4^{\mathrm{Bb}}$ & $167.0^{\mathrm{Ba}}$ \\
\hline 5 & $98.2^{\mathrm{Ad}}$ & $121.5^{\mathrm{Ac}}$ & $144.0^{\mathrm{Ab}}$ & $187.4^{\mathrm{Aa}}$ \\
\hline Mean & 60.0 & 95.2 & 109.9 & 142.1 \\
\hline \multirow[t]{2}{*}{ SE } & 0.7 & 1.9 & 7.2 & 1.4 \\
\hline & \multicolumn{4}{|c|}{ Panicum maximum cv Mombaça } \\
\hline 1 & $28.1^{\mathrm{Ec}}$ & $66.0^{\mathrm{Eb}}$ & $74.6^{\mathrm{cab}}$ & $89.8^{\mathrm{Da}}$ \\
\hline 2 & $40.4^{C D C}$ & $77.2^{\mathrm{DEb}}$ & $83.1^{\mathrm{cb}}$ & $112.9^{\mathrm{ca}}$ \\
\hline 3 & $46.8^{B C C}$ & $83.5^{\mathrm{CDb}}$ & $113.1^{\mathrm{Ba}}$ & $125.2^{\mathrm{BCa}}$ \\
\hline 4 & $57.6^{B C}$ & $98.0^{B C b}$ & $134.7^{\mathrm{Aa}}$ & $139.2^{\mathrm{ABa}}$ \\
\hline 5 & $73.6^{\mathrm{Ad}}$ & 107. $0^{A B C}$ & $139.5^{\mathrm{Ab}}$ & $152.4^{\mathrm{Aa}}$ \\
\hline Mean & 49.3 & 86.3 & 109.0 & 123.9 \\
\hline \multirow[t]{2}{*}{ SE } & 3.8 & 1.9 & 5.1 & 2.1 \\
\hline & \multicolumn{4}{|c|}{ Pennisetum purpureum cv Cameroon } \\
\hline 1 & $39.1^{\mathrm{cc}}$ & $70.4^{\mathrm{cb}}$ & $93.5^{\mathrm{Ca}}$ & $103.3^{\mathrm{Ea}}$ \\
\hline 2 & $56.5^{B C}$ & $83.0^{B b}$ & $136.1^{\mathrm{Ba}}$ & $127.7^{\mathrm{Da}}$ \\
\hline 3 & $57.2^{B C}$ & $93.9^{\mathrm{Bb}}$ & $139.7^{\mathrm{Ba}}$ & $133.5^{\mathrm{CDa}}$ \\
\hline 4 & $59.9^{B d}$ & $114.5^{\mathrm{AC}}$ & $155.1^{\mathrm{Aa}}$ & $144.2^{\mathrm{BCb}}$ \\
\hline 5 & $72.6^{\mathrm{Ac}}$ & $119.6^{\mathrm{Ab}}$ & $159.0^{\mathrm{Aa}}$ & $167.5^{\mathrm{Aa}}$ \\
\hline Mean & 57.1 & 96.3 & 136.7 & 135.2 \\
\hline \multirow[t]{2}{*}{ SE } & 2.4 & 1.2 & 2.9 & 1.2 \\
\hline & \multicolumn{4}{|c|}{ Pennisetum purpureum cv Napier } \\
\hline 1 & $43.5^{\mathrm{Cd}}$ & $76.6^{D C}$ & $97.1^{\mathrm{Db}}$ & $108.7^{\text {Ea }}$ \\
\hline 2 & $52.9^{B C C}$ & $84.1^{\mathrm{Db}}$ & $113.0^{\mathrm{Ca}}$ & $121.2^{\mathrm{Da}}$ \\
\hline 3 & $58.3^{\mathrm{BC}}$ & $99.0^{\mathrm{cb}}$ & $135.7^{\mathrm{Ba}}$ & $134.9^{\mathrm{ca}}$ \\
\hline 4 & $62.5^{B C}$ & $117.5^{\mathrm{Bb}}$ & $143.1^{\mathrm{ABa}}$ & $150.4^{\mathrm{Ba}}$ \\
\hline 5 & $75.5^{\mathrm{Ad}}$ & $127.1^{\mathrm{Ac}}$ & $148.5^{\mathrm{Ab}}$ & $170.5^{\mathrm{Aa}}$ \\
\hline Mean & 58.5 & 100.9 & 127.5 & 137.1 \\
\hline SE & 1.9 & 1.3 & 5.2 & 2.4 \\
\hline
\end{tabular}

$\mathrm{DM}$, dry matter; SE, standard error of the mean; $\mathrm{ADL}$, acid detergent lignin; $\mathrm{KL}$, Klason lignin; PerL, permanganate lignin; ABL, acetyl bromide lignin.

Means by specie, within columns for maturity followed by different capital letters or, within rows for analitycal method followed by different lower-case letters are different according to Fisher's LSD $(p<0.05)$.

(Table 2).

Lignin values yielded by PerL method ranged from $65.5 \mathrm{~g} / \mathrm{kg}$ DM to $159.0 \mathrm{~g} / \mathrm{kg}$ DM for Brachiaria brizantha cv Marandú and Pennisetum purpureum cv Cameroon, respectively. In this study, KL values ranged from $61.4 \mathrm{~g} / \mathrm{kg}$ DM to $127.1 \mathrm{~g} / \mathrm{kg} \mathrm{DM}$ for Brachiaria brizantha cv Xaraés and Pennisetum purpureum cv Napier, respectively. The PerL and KL values observed in 
this study were approximately double the values observed for $\mathrm{ADL}$. The values for ABL method were the highest among the methods. Values ranged from $89.8 \mathrm{~g} / \mathrm{kg}$ DM for Panicum maximum cv Mombaça to $187.4 \mathrm{~g} / \mathrm{kg}$ DM for Brachiaria brizantha cv Xaraés.

\section{In vitro forage degradability}

No differences were observed for IVDMd $(\mathrm{p}=0.34)$ or IVNDFd $(\mathrm{p}=0.38)$ among the grass species at a given maturity. As expected, in vitro dry matter degradability (IVDMd) inversely followed maturity stages. Mean values ranged from $487.6 \mathrm{~g} / \mathrm{kg}$ DM for Brachiaria brizantha cv Xaraés to $547.4 \mathrm{~g} / \mathrm{kg}$ DM for Pennisetum purpureum cv Cameroon. In vitro neutral detergent fiber degradability (IVNDFd) had the same pattern of IVDMd as the plants matured. Mean IVNDFd values were numerically lower than IVDMd values, ranging from $360.7 \mathrm{~g} / \mathrm{kg}$ NDF to $430.7 \mathrm{~g} / \mathrm{kg}$ NDF for Brachiaria brizantha cv Marandú and Pennisetum purpureum cv Napier, respectively.

\section{Correlations}

Negative correlations between lignin contents and IVDMd or IVNDFd were observed for all four methods. Higher correlations were observed for IVDMd than for IVNDFd. Correlations for IVDMd ranged from $-0.69(r<0.0001)$ for PerL to -0.81 $(r<0.0001)$ for KL. For IVNDFd, correlations ranged from $-0.54(r<0.0001)$ to $-0.68(r<0.0001)$ for PerL and KL, respectively.

\section{DISCUSSION}

\section{Chemical composition}

Increase in the DM content is due, primarily, to increase of CW structural elements [1]. As plants mature, the CW fraction gradually increases and so does the DM content, considering that up to $80 \%$ of all DM is composed of CW. This was observed by the increased values of fibrous fractions (NDF, ADF, and CW) (Table 1).

Ash and protein contents were measured in CW and NDF fractions. These substances have long been known to be present in these fibrous fractions and the corrections are made simply because they are not considered fiber, from a nutritional point of view, even though protein plays a key structural role inside the plant cellular wall [19]. Values of ash and protein residues in the CW and NDF fractions were low, as was expected for grass species. Obviously, for both fibrous fractions, the corrected values were lower than their corresponding uncorrected values. Although the values for ash/protein residues were not high, in some cases like Marandú and Cameroon they represented up to $10 \%$ of the $\mathrm{CW}$ fraction (Obs: these grasses were cultivated in experimental plots, thus soil contamination may not have played an important role).

Differences between CW and NDF were on account of SF loss during NDF extraction. The CW preparation preserves the majority of its components [20], because only water and organic solvents are used to extract the cell solubles. On the other hand, NDF preparation uses a detergent that solubilizes pectin and other polysaccharides (such as $\beta$-glucans, galactans, gums, etc.). These neutral detergent soluble carbohydrates are referred to as SF [21]. Given its importance, Queiroz et al [18] proposed the creation of a specific carbohydrate fraction, $\left(\mathrm{B}_{2}\right)$, for SF if using the Cornell Net Carbohydrate and Protein System. Generally speaking, SF is a minor component of the CW structure; however, for some species, like Brachiaria bri$z a n t h a$ cv Marandú, this fraction represented as much as $20 \%$ of the total CW components (Table 1). This aspect may be advantageous to the animal for pectin is almost completely degraded in the rumen [11].

\section{Lignin concentrations}

The gravimetric method ADL is probably the most widely used method for lignin determination in Agronomy and Animal Sciences. Our study showed low lignin values (Table 2 ). Several others $[2,3,8,22]$ have consistently reported that the values obtained by this method are lower than values obtained by other procedures.

These lower values may be due to partial solubilization of lignin in ADS [4,5,7,23]. Lignin is located inside the CW, covalently linked to hemicellulose, surrounded by cellulose in a tridimensional structure [24]. The dissolution of hemicellulose by the ADS leaves lignin in a loose arrangement from which part of it can be removed and later lost during washing [6].

On the other hand, KL has been known to be contaminated with protein or structural carbohydrate residues that are not completely hydrolyzed [8]. These authors reported that $\mathrm{KL}$ values could be as much as three times ADL values because of the combination involving loss of lignin in the ADL method plus protein and carbohydrate contamination in the KL method. The present study showed that KL values were, on average, 1.7 times ADL values. According to Van Soest [1] some tanniferous compounds are solubilized by the ADS, whereas KL can contain a variety of condensed tannins and tannin-protein compounds. In some species, specially legumes, these compounds can contribute to the differences observed between ADL and KL.

Another analytical method for lignin quantification, the PerL procedure uses the same fibrous substrate as the ADL method does. PerL values were higher than ADL concentrations, varying from 1.8 to 2.4 times (Table 2). The PerL values have been known to be affected by pectin presence in the $\mathrm{ADF}$ residue [9]. Usually grasses contain relatively low concentrations, so the potential for interference is considered low. However, Table 1 shows the values of SF ranging from 25.3 to $99.8 \mathrm{~g} / \mathrm{kg}$ of DM. Considering that pectin probably constitutes more than half of the SF fraction it could impact PerL values. 
In spite of these findings, the PerL method is still used by researchers who prefer avoiding utilization of highly corrosive $72 \%$ sulfuric acid.

The spectrophotometric method ABL was initially developed for the wood industry and later modified for its use in forages [10]. Until recently one important setback was the lack of an acceptable standard to which readings of unknown samples could be compared to [20]. Then, Fukushima and Kerley [14] proposed a regression equation, obtained from the calibration curves of several plants, that can be used to determine the lignin content in any plant species. The present study showed the highest lignin values for the ABL method. However, the supposedly high lignin concentrations could be caused by esters of hidroxycinamic acids that are loosely bound to the plant CW [25]. Being a spectroscopic method, ABL would be able to detect soluble lignin components that would be lost in conventional gravimetric methods. The presence of these acids could explain the high absorbance values [26], especially in grass species where they are found in higher concentrations [27].

Morrison and Stewart [26] had mentioned that this difference may be the reason why distinct regression equations had to be used for grasses and legumes to convert absorbance values to lignin contents. However, recent data [7] relating ABL method with in vitro degradability assays showed that slopes between grasses and legumes had similar inclinations.

Another question that arises around the ABL method is that it could detect other phenol-containing compounds (protein, tannins, flavonoids) that absorb UV light in the same region where lignin absorbs $(280 \mathrm{~nm})$. The ABL method uses the fibrous preparation CW [20]. During its preparation, tannins and flavonoids are removed [10], therefore these compounds would not pose a problem. In regards to a possible interference of CW protein in the absorbance readings, Morrison [10] analyzed the precipitate formed after $\mathrm{CW}$ digestion in the $25 \%$ acetyl bromide solution and concluded that it was mainly protein. Fukushima found protein content in this precipitate varying from 515.4 to $693.0 \mathrm{~g} / \mathrm{kg}$; the remaining sediment was mineral matter (data not published). Thus, these substances probably do not interfere with the optical density readings used to determine lignin concentration.

\section{Correlation with in vitro forage degradability}

Correlation between lignin concentration measured by a specific analytical method and an in vitro degradability (Table 3 ) assay is one tool that can assist in the characterization of an analytical method. The chemical accuracy of nutrient determination improves the degree of correlation and is therefore of critical importance [28]. Even though the degree of correlation may be unsatisfactory for some situations, this index reflects the practicality of being able to obtain a more accurate estimate of nutritive value from chemical compositional data
Table 3. Correlations between lignin contents ( $/ \mathrm{kg}$ DM) obtained by different methods and IVDMD and IVNDFD

\begin{tabular}{lcccccc}
\hline \multirow{2}{*}{ Method } & \multicolumn{7}{c}{ Method } \\
\cline { 2 - 7 } & ADL & KL & PerL & ABL & IVDMD & IVNDFD \\
\hline ADL & 1.0 & - & - & - & - & - \\
KL & 0.9352 & 1.0 & - & - & - & - \\
$r$ & $<0.0001$ & - & & & & \\
PerL & 0.7324 & 0.7425 & 1.0 & - & - & - \\
$r$ & $<0.0001$ & $<0.0001$ & - & - & & \\
ABL & 0.9750 & 0.9594 & 0.7498 & 1.0 & - & - \\
$r$ & $<0.0001$ & $<0.0001$ & $<0.0001$ & - & - & - \\
IVDMD & -0.7627 & -0.8072 & -0.6869 & -0.7964 & 1.0 & - \\
$r$ & $<0.0001$ & $<0.0001$ & $<0.0001$ & $<0.0001$ & - & - \\
IVNDFD & -0.6140 & -0.6822 & -0.5356 & -0.6367 & 0.8953 & 1.0 \\
$r$ & $<0.0001$ & $<0.0001$ & $<0.0001$ & $<0.0001$ & $<0.0001$ & - \\
\hline
\end{tabular}

DM, dry matter; IVDMD, in vitro dry matter degradability; IVNDFD, in vitro neutral detergent fiber degradability; ADL, acid detergent lignin; KL, Klason lignin; PerL, permanganate lignin; $A B L$, acetyl bromide lignin.

[12].

Figure 2 shows that correlations within IVNDFd were lower than the correlations within IVDMd. It was expected that expressing lignin per unit of NDF would improve its correlation with CW degradability, but this study showed the opposite. Because lignin impacts only $\mathrm{CW}$ degradation, not non-CW components (non-NDF components are virtually $100 \%$ degradable), it has been suggested that expressing lignin on a DM basis should be avoided [1]. Jung and Vogel [29] found that lignin as a percentage of DM gave an equal or better fit to the model than lignin as a percentage of NDF, and attributed their observations to a greater precision in determination of DM compared to NDF. In addition, Traxler et al [30] reported a better correlation between the unavailable residue of NDF and the lignin concentration of DM, rather than the lignin concentration of NDF.

The PerL method gave the lowest correlation coefficients then, it may not reliably estimate the degradability of tropical grasses. This may be caused by the interference of substances such as pectin, tannins or flavonoides that are oxidized by the $\mathrm{KMnO}_{4}$ solution [9]. In an experiment conducted in our laboratory (data not published), the tannin and total phenols contents were quantified in crude CW of grasses (9.5 to 35.5 $\mathrm{g} / \mathrm{kg} \mathrm{DM}$ ) and legumes (11.3 to $80.6 \mathrm{~g} / \mathrm{kg}$ ). Therefore, they could appear as an artifact of the PerL technique. According to Van Soest and Wine [9], these phenolic compounds could represent a bias mainly in tanniferous plants. Also, PerL uses $\mathrm{ADF}$ as substrate for lignin analysis and therefore suffers from the same restrictions as the ADL method that were previously discussed.

Even though ADL and KL methods yielded different lignin values, they had similar correlations with degradability and therefore, could estimate degradability of forages with comparable accuracy. Figures 1 and 2 illustrate that the slopes of 


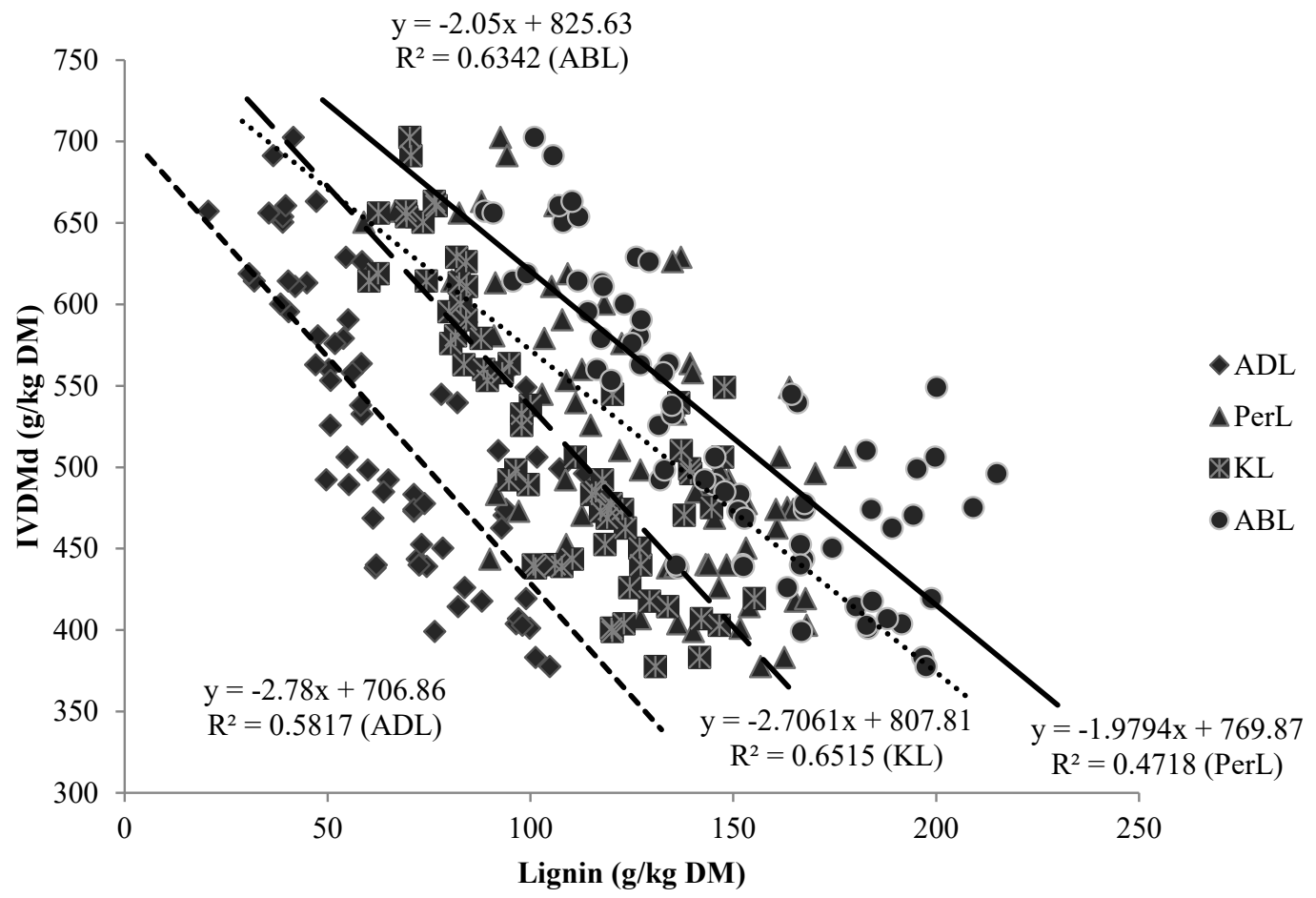

Figure 1. Regression parameters for the relationship between lignin contents, obtained by different methods, and in-vitro DM digestibility. DM, dry matter; ADL, acid detergent lignin; PerL, permanganate lignin; KL, Klason lignin; ABL, acetyl bromide lignin.

both methods were much the same and curves were parallel. Similar correlation coefficients were also obtained by Jung et al [3]. These authors found that both lignin methods were generally negatively correlated with DM and NDF degradability

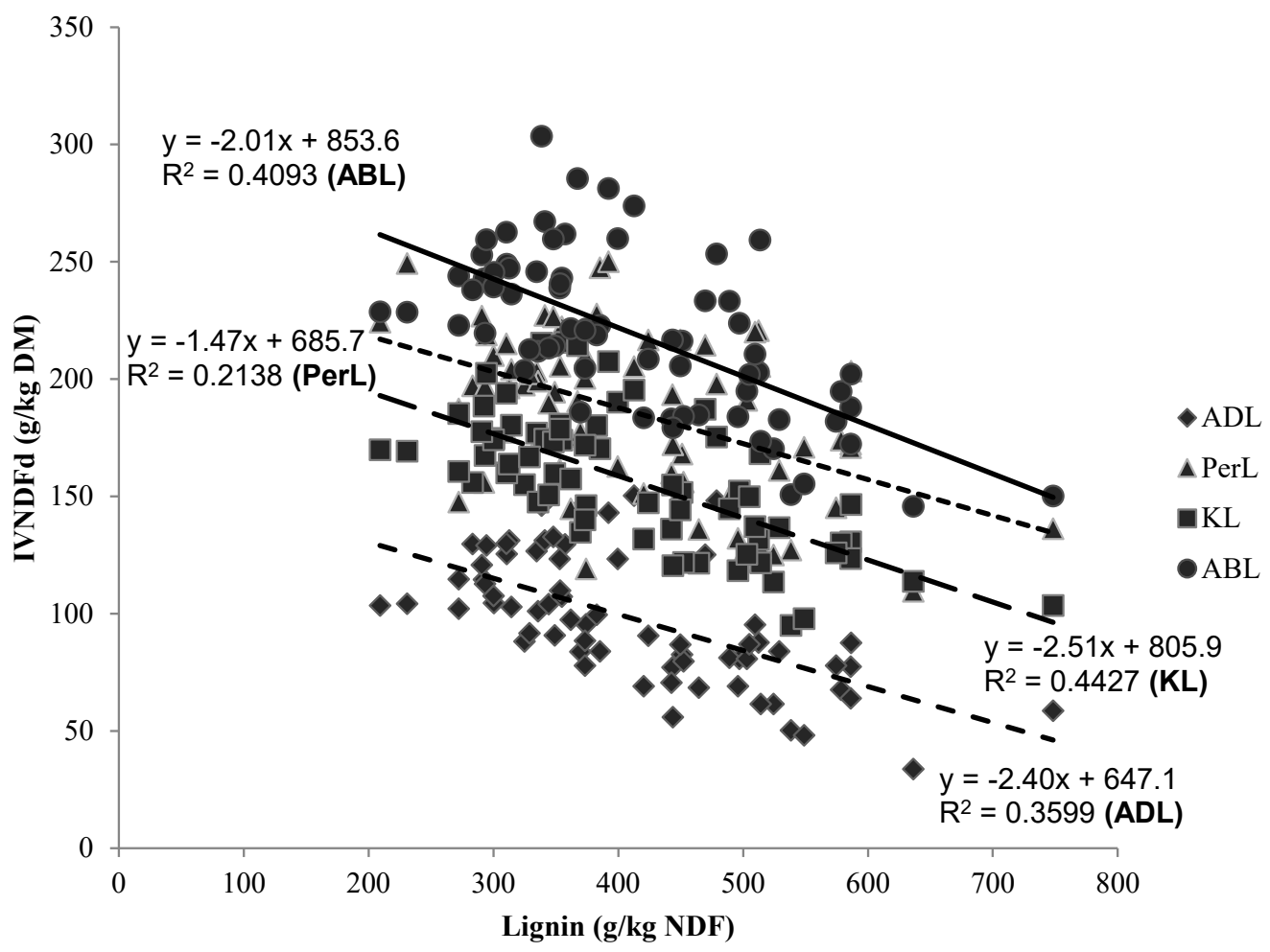

Figure 2. Regression parameters for the relationship between lignin contents, obtained by different methods, and in-vitro NDF digestibility. NDF, neutral detergent fiber; $A D L$, acid detergent lignin; PerL, permanganate lignin; KL, Klason lignin; $A B L$, acetyl bromide lignin. 
in both in vitro and in vivo systems. They stated that, both methods had similar degree of correlation with degradability of forages but, KL could produce a more accurate measurement of total lignin content than ADL, especially in grasses. Hatfield et al [8] found conflicting concentrations for the ADL and KL methods but suggested that the KL method could produce more accurate results.

This work showed that the ABL method had comparably good correlations. Fukushima et al [7] reported highest correlation coefficients for ABL when compared to other analytical methods, for both grass and legume degradation.

The pattern observed for in vitro forage degradability values confirms the physiological changes in the composition of forages as they mature and the implications of these changes on microbial degradation. Lignin concentration was linearly associated to IVDMd and IVNDFd (Figures 1, 2, respectively). This had already been reported by other authors $[13,24]$. The elevated correlations observed in this study inferred that the methods $\mathrm{ADL}, \mathrm{KL}$ and $\mathrm{ABL}$ ranged evenly within the five species and five maturity stages.

\section{CONCLUSION}

Even though this study showed varying results obtained by different lignin methods, it is important to notice that correlations were high between degradability of DM and the methods ADL, KL, and ABL. However, both ADL and KL methods use strong acids that require adequate manipulation and it is recommended that ash be determined in the lignin residues, which increases labor and time of analysis. Nitrogen contamination in the $\mathrm{KL}$ residue is also advisable to quantify. In the ABL method there is no need for such corrections. Further studies, involving a wider range of species including legumes, are needed. Nevertheless, the ABL method is convenient for determination of total lignin content in plants and a good option for routine laboratory analysis.

\section{IMPLICATIONS}

This study provides data to better understand the relationship between lignin concentration and implications with tropical forage degradation. It is also an effort towards the standardization of a reliable, safe and fast method for lignin quantity assays. The spectrophotometric method is a safer procedure when compared against sulfuric acid lignin methods. Information about its use can stimulate interest in the method by the scientific community and allow for expansion of its use in routine laboratory analysis. An accurate procedure for lignin quantification could help to better understand how ruminant animals use forages and improve milk and meat production.

\section{CONFLICT OF INTEREST}

We certify that there is no conflict of interest with any financial organization regarding the material discussed in the manuscript.

\section{ACKNOWLEDGMENTS}

The authors are grateful to "Fundação de Amparo à Pesquisa do Estado de São Paulo (FAPESP)" for funding this study (Research grant number 2013/07430-0) and graduate student's fellowships from "Coordenação de Aperfeiçoamento de Pessoal de Nível Superior (CAPES)".

\section{REFERENCES}

1. Van Soest PJ. Nutritional ecology of the ruminant. Second edition. Ithaca, NY, USA: Cornell University Press, 1994.

2. Hatfield R, Fukushima RS. Can lignin be accurately measured? Crop Sci 2005;45:832-9.

3. Jung HG, Mertens DR, Payne AJ. Correlation of acid detergent lignin and Klason lignin with digestibility of forage dry matter and neutral detergent fiber. J Dairy Sci 1997;80:1622-8.

4. Shimojo M, and Goto I. A study on the relation between disappearance of dry matter and acetyl bromide lignin of tropical grass. Anim Sci J 1984;55:838-42.

5. Kondo T, Mizuno K, Kato T. Some characteristics of forage plant lignin. Jpn Agric Res Q 1987;21:47-52.

6. Lowry JB, Conlan LL, Schlink AC, McSweeney CS. Acid detergent dispersible lignin in tropical grasses. J Sci Food Agric 1994;1:41-9.

7. Fukushima RS, Kerley MS, Ramos MH, Porter JH, Kallenbach RL. Comparison of acetyl bromide lignin with acid detergent lignin and Klason lignin and correlation with in vitro forage degradability. Anim Feed Sci Technol 2015;201:25-37.

8. Hatfield RD, Jung HJ, Ralph J, Buxton DR, Weimer PJ. A comparison of the insoluble residues produced by the klason lignin and acid detergent lignin procedures. J Sci Food Agric 1994; 65:51-8.

9. Van Soest PJ, Wine RH. Determination of lignin and cellulose in acid-detergent fiber with permanganate. J Assoc Off Anal Chem 1968;51:780-5.

10. Morrison IM. Semi-micro method for determination of lignin and its use in predicting digestibility of forage crops. J Sci Food Agric 1972;23:455-63.

11. Van Soest PJ, Robertson JB, Lewis BA. Methods for dietary fiber, neutral detergent fiber, and nonstarch polysaccharides in relation to animal nutrition. J Dairy Sci 1991;74:3583-97.

12. Van Soest PJ, Robertson JB. Systems of analysis for evaluating fibrous feeds. In: Pigden WJ, Balch CC, Graham M, editors. Standardization of analytical methodology for feeds. Ottawa, ON, Canada: International Development Research Center; 
1980.

13. Mertens DR. Impact of NDF content and digestibility on dairy cow performance. WCDS Adv Dairy Technol 2009;21:191201.

14. Fukushima RS, Kerley MS. Use of lignin extracted from different plant sources as standards in the spectrophotometric acetyl bromide lignin method. J Agric Food Chem 2011;59:3505-9.

15. Tilley JA, Terry RA. Two stages techniques for in vitro digestion of forage crops. J Br Grassl Soc 1963;18:104-11.

16. Fukushima RS, Weimer PJ, Kunz DA. Photocatalytic interaction of resarzurin $\mathrm{N}$-Oxide with cysteine optimizes preparation of anaerobic culture media. Anaerobe 2002;8:29-34.

17.SAS Institute, Inc, SAS User's Guide: Sattistics, Version 9.1. Cary, NC, USA: SAS Institute, Inc.; 2003.

18. Queiroz MAA, Fukushima RS, Gomide CA, Braga MR. Substitution of crude cell wall for neutral detergent fibre in the equations of the Cornell Net Carbohydrate and Protein System that predict carbohydrate fractions: application to sunflower (Helianthus annuus L.). Animal 2008;2:1087-92.

19.Udén P, Robinson PH, Wiseman J. Use of detergent system terminology and criteria for submission of manuscripts on new, or revised, analytical methods as well as descriptive information on feed analysis and/or variability. Editorial. Anim Feed Sci Technol 2005;118:181-6.

20. Fukushima RS, Hatfield RD. Comparison of the acetyl bromide spectrophotometric method with other analytical lignin methods for determining lignin concentration in forage samples. J Agric Food Chem 2004;52:3713-20.
21. Hall MB, Lewis BA, Van Soest PJ, Chase LE. A simple method for estimating of neutral detergent-soluble fibre. J Sci Food Agric 1997;74:441-9.

22. Moore KJ, Jung HJG. Lignin and fiber digestion. J Range Manag 2001;54:420-39.

23.Jung HG, Fahey GC. Nutritional implications of phenolic monomers and lignin - a review. J Anim Sci 1983;57:206-19.

24. Weimer PJ, Stevenson DM, Mertens DR, Hall MB. Fiber digestion, VFA production, and microbial population changes during in vitro ruminal fermentations of mixed rations by monensin-adapted and unadapted microbes. Anim Feed Sci Technol 2011;169:68-78.

25. Fahey GC, Jung HG. Lignin as a marker in digestion studies - a review. J Anim Sci 1983;57:220-5.

26. Morrison IM, Stewart D. Determination of lignin in the presence of ester-bound substituted cinnamic-acids by a modified acetyl bromide procedure. J Sci Food Agric 1995;69:151-7.

27. Jung HG, Deetz DA. Cell-wall lignification and degradability. In: Jung HJ, Buxton DR, Hatfield RD, Ralph J, editors. Forage cell wall structure and digestibility. Madison, WI, USA: ASACSSA-SSSA; 1993.

28. Fonnesbeck PV, Harris LE, Kearl LC. Estimating nutritive values from chemical-analyses. J Anim Sci 1975;41:1150-84.

29. Jung HG, Vogel KP. Influence of liginin on digestibility of forage cell wall material. J Anim Sci 1986;62:1703-12.

30. Traxler MJ, Fox DG, Van Soest PJ, et al. Predicting forage indigestible NDF from lignin concentration. J Anim Sci 1998; 76:1469-80. 